\title{
DUKUNGAN SOSIAL HUBUNGANNYA DENGAN MOTIVASI MENJADI COSPLAYER PADA COSMIC (COSPLAYER MINANG COMMUNITY) PADANG
}

\author{
Mukhlisan Darwan, Isna Asyri Syahrina, Ria Okfrima \\ Fakultas Psikologi Universitas Putra Indonesia "YPTK” Padang \\ Email : isnasyeko@gmail.com
}

\begin{abstract}
The purpose of this research is to find out whether there is a relationship between social support and motivation to become a cosplayer in COSMIC (cosplayer Minang Community) in Padang. The independent variable in this study is social support and the dependent variable is the motivation to be a cosplayer. The measuring instrument used in this study is the scale of social support and the motivation scale of being a cosplayer. The population in this study amounted to 47 people. The sample technique in this study used a saturated sampling technique. Saturated sampling is a sampling technique if all members of the population are used as samples. Samples in this study amounted to 47 people. Test the validity and reliability usingTechnique Cronbach Alpha. The item different power index on the social support scale moves from 0.337 to 0.793 , while the motivation scale becomes a cosplayer moves from 0.330 to 0.741 . The reliability coefficient on the social support scale is 0.890 , while the reliability coefficient on the motivation scale becomes cosplayer at 0.893 . Hypothesis test results show the correlation coefficient of 0.296 with a significant level $\mathrm{p}=0.043$ means that there is a significant relationship between social support and motivation to become cosplayers in Padang, with the effective contribution of social support to motivation to become cosplayers in Padang by $9 \%$ and $91 \%$ influenced other factors. So there is a relatively low relationship between social support variables and the motivation to become cosplayers.
\end{abstract}

Keywords :Social support, Motivation, Cosplayers

\begin{abstract}
ABSTRAK
Tujuan penelitian ini adalah untuk mengetahui apakah terdapat hubungan antara Dukungan sosial dengan Motivasi menjadi Cosplayer pada COSMIC (Cosplayer Minang Community) di Padang. Variabel bebas dalam penelitian ini adalah dukungan sosial dan variable terikat adalah motivasi menjadi cosplayer. Alat ukur yang digunakan dalam penelitian ini adalah skala dukungan sosial dan skala motivasi menjadi cosplayer. Populasi dalam penelitian ini berjumlah 47 orang. Teknik sampel dalam penelitian ini menggunakan teknik sampling jenuh. Sampling jenuh adalah teknik penentuan sampel bila semua anggota populasi digunakan sebagai sampel.Sampel dalam penelitian ini berjumlah 47 orang. Uji validitas dan reabilitas menggunakan Teknik Alpha Cronbach. Indeks daya beda aitem pada skala dukungan sosial bergerak dari 0,337 sampai 0,793, sedangkan pada skala motivasi menjadi cosplayer bergerak dari 0,330 sampai 0,741.Koefisien reliabilitas pada skala dukungan sosial sebesar 0,890, sedangkan koefisien reliabilitas pada skala motivasi menjadi cosplayer sebesar 0,893. Hasil uji hipotesis menunjukkan besarnya koefisien kolerasi sebesar 0,296 dengan taraf signifikan $\mathrm{p}=$ 0,043 artinya terdapat hubungan yang signifikan antara dukungan sosial dengan motivasi menjadi cosplayer di Padang, dengan besarnya sumbangan efektif dukungan sosia lterhadap motivasi menjadi cosplayer di Padang sebesar 9\% dan 91\% lagi dipengaruhi faktor lain. Jadi terdapat hubungan yang tergolong rendah antara variabel dukungan sosial dengan motivasi menjadi cosplayer.
\end{abstract}

Kata Kunci :Dukungan sosial, Motivasi , Cosplayer

\section{PENDAHULUAN}

Manusia pada dasarnya merupakan makhluk yang meniru segala hal yang membuatnya tertarik, bahkan sejak kecil manusia sudah mulai meniru kegiatan ataupun hal hal yang dilakukan oleh orang sekitarnya, terutama keluarga. Sifat meniru ini sudah bawaan manusia sebagai makhluk social, perilaku meniru ini bisa didapat dari pengalaman sebagai 
pembelajaran, lingkungan sekitar, ataupun hal lainnya seperti pengaruh televisi, video game, ataupun pengaruh budaya luar yang masuk ke suatu daerah.

Budaya Jepang merupakan salah satu budaya yang masuk ke Indonesia dan berkembang pesat. Jepang sebagai salah satu negara maju di Asia Timur merupakan tujuan wisata budaya yang sangat menarik. Upacara minum teh (chanoyu), seni merangkai bunga (ikebana), dan seni melipat kertas (origami) merupakan produk budaya Jepang yang sudah dikenal masyarakat Indonesia terutama pelajar dan peminat budaya Jepang (Fadhilah dalam Pratiwi 2014). Menurut Fadhilah (2014) produk budaya populer Jepang seperti game dan anime begitu lekat dalam keseharian anak-anak Indonesia. Film animasi Doraemon merupakan produk budaya populer Jepang yang ditayangkan di televisi swasta Indonesia sejak tahun 80-an hingga saat ini. Film kartun tersebut sangat digemari oleh anak-anak, bahkan media hiburan seperti karaoke dan costume player (cosplay) muncul di kalangan remaja, sehingga menjadi media ekspresi dan kreativitas (Fadilah dalam Pratiwi 2014). Kegiatan cosplay atau costume play semakin marak di Indonesia. Anak-anak muda hingga orang dewasa menjadikan kegiatan berpakaian, berdandan, dan mengenakan aksesoris menyerupai karakter anime ini sebagai hobi. Cosplay adalah jenis seni pertunjukan beberapa orang yang berkostum sebagai karakter fiksi. Karakter tersebut berasal dari novel grafis, komik, anime, video game, media fiksi ilmiah atau fantasi (Winge dalam Pratiwi 2014).

Fenomena tersebut juga terjadi di kota Padang. Kota Padang dengan budaya Minangkabau yang sangat berbeda jauh dengan budaya Jepang, banyaknya muncul komunitas yang berfokus pada anime, dan cosplay, dimana peminatnya dari kalangan anakanak, remaja, hingga dewasa. Hal ini tidak terlepas dari pengaruh media sosial yang memudahkan kita untuk dapat mengetahui berbagai informasi tentang daerah lain, salah satunya juga dapat mengakses program atau acara televisi yang menjadi produck andalan jepang yaitu kartun jepang atau anime (animasi jepang). Penikmat animasi Jepang terdiri dari kalangan anak-anak hingga dewasa, Dimulai dari ditayangkannya animasi-animasi jepang pada siaran televisi nasional pada tahun 2000-an, penikmatnya terus bertambah hingga saat ini, saat ini berkat kemajuan teknologi kita bisa mengakses dengan cara mendownload film animasi yang diminati secara gratis, hal ini mengakibatkan makin maraknya hal yang berhubungan dengan jepang masuk ke Indonesia, di Padang sendiri juga ada pencinta anime tersebut, mulai dari banyaknya terdapat tempat makan khusus masakan Jepang, acara-acara seperti kontes, festival, dan termasuk munculnya komunitas pencinta anime di Padang.

Anime merupakan animasi khas Jepang yang biasanya dicirikan melalui gambargambar berwarna-warni yang menampilkan tokoh-tokoh dalam berbagai macam lokasi dan cerita, yang ditujukan pada beragam jenis penonton baik itu anak-anak hingga orang dewasa. Anime tidak hanya bersifat menghibur, tetapi biasanya terdapat pesan-pesan moral yang bagus, banyak pelajaran-pelajaran kehidupan yang bisa diambil, banyak juga menginspirasi ketika menonton anime, baik itu dari gaya berbusana maupun karakter dari tokoh anime tersebut. Bisa terlihat dari acara festival Jepang yang biasa diadakan di Indonesia, mereka menggunakan cosplay. Mereka dengan bangga memakai kostum seperti tokoh anime favorit mereka, dan bahkan ada juga yang meniru dari karakter anime misalnya tokoh favoritnya punya sifat pantang menyerah, kemudian sifatnya itu ditiru oleh fans tokoh tersebut. Beberapa kampus di Padang seperti Universitas Negeri Padang (UNP), Universitas Andalas (UNAND), dan Universitas Bung Hatta (UBH) setiap tahunnya mengadakan acara Bunkasai, yaitu festival Jepang dikampus dengan mengadakan berbagai pertunjukan dan menjual makanan jepang, tak terkecuali cosplay sebagai acara utama dalam setiap pertunjukan bunkasai.

Dari wawancara dan observasi yang telah peneliti lakukan terhadap beberapa orang dari komunitas cosplayer di Padang, ditemukan bahwa komunitas mereka telah terbentuk dan menekuni hobbi menjadi cosplayer kurang lebih 4 tahun, berawal dari hobi dan ketertarikan 
menonton anime hingga menjadi antusias bukan sekedar menikmati filmnya saja, tetapi ingin mencoba menjadi salah satu karakter anime yang ditonton. Mereka mengatakan bahwa, masalah selama ini menjadi cosplayer adalah tidak mendapatkan dukungan dari pihak keluarga, peralatan kostum yang telah dibuat dengan usaha sendiri dibuang oleh orang tua saat mereka tidak berada di rumah, namun setelah itu mereka tetap melanjutkan hobinya, tetap melakukan kegiatan cosplay dan tetap ikut tampil dalam acara festival Jepang yang diadakan di Padang. Ditemukan juga terdapat anggapan dari beberapa teman mereka bahwa hobi yang dilakukan ini aneh atau kekanak-kanakan. Selanjutnya hasil wawancara dari komunitas cosplayer yang selanjutnya ditemukan bahwa mereka mendapatkan dukungan dan kesan positif dari orang tua dan teman-teman. Kegiatan menjadi cosplayer sangat menyenangkan dan selalu membuatnya bersemangat, menurut mereka orang tua sangat mendukung kegiatan yang mereka lakukan, karena selain dapat aktif dalam bersosialisasi dalam suatu kelompok, kegiatan ini juga menambah wawasan dan kreativitas, karena mendapatkan dukungan dari orang tua dan teman-teman dan sampai saat ini, sudah 2 tahun mereka aktif menjadi anggota cosplayer di Padang. Selanjutnya hasil wawancara dengan komunitas ketiga ditemukan bahwa mereka telah aktif menjadi cosplayer selama 1 tahun, mereka termotivasi tidak hanya karena menyukai karakter yang diperankan, tetapi mereka beranggapan bahwa kegiatan tersebut juga menambah ilmu seperti, menjahit kostum, membuat replika senjata atau aksesoris dari kayu, dan juga menurut mereka kegiatan ini bisa menghasilkan uang. Awalnya kegiatan ini mendapat pandangan negatif dari teman-temannya, karena dianggap hobi yang tidak jelas dan menghambur-hamburkan uang. Wawancara dengan ketua COSMIC Padang ditemukan bahwa yang menjadi masalah dalam komunitas cosplay adalah adanya para anggota yang tidak atau kurang loyal dalam melakukan kegiatan rutin bulanan, terkadang dalam berkumpul itu hanya setengah dari total anggota yang ikut berkumpul.

\section{Motivasi menjadi Cosplayer}

Menurut Santrock (dalam Kompri, 2015), motivasi adalah proses yang memberi semangat, arah, dan kegigihan perilaku. Artinya perilaku yang termotivasi adalah perilaku yang penuh energi, terarah, dan bertahan lama. Selanjutnya Morgan (dalam Soemanto, 2012) menyebutkan "Motivation is a general term referring to states that motivate behavior, to the behavior motivated by these states, and to the goals or ends or such behavior". Ia menyatakan motivasi merupakan istilah umum yang mengacu pada kondisi-kondisi yang mendorong perilaku, kondisi-kondisi dorongan tingkah laku dan tingkah laku untuk mencapai tujuan atau sasaran akhir. Jadi motivasi adalah dorongan dari dalam atau luar diri seseorang untuk mencapai suatu tujuan.

Motivasi merupakan perubahan energi dalam diri seseorang dalam bentuk suatu aktivitas nyata berupa kegiatan fisik. Karena seseorang mempunyai tujuan tertentu dari aktivitasnya, maka seseorang mempunyai motivasi yang kuat untuk mencapainya dengan segala upaya yang dapat dia lakukan untuk mencapainya (dalam Suardana dan Simarmata, 2013).

Hal ini berkaitan dengan segala usaha dan upaya yang dilakukan oleh para cosplayer dalam mencapai tujuannya. Winge (dalam Pratiwi, 2014) mengatakan bahwa cosplayer tidak hanya berdandan namun mengenakan kostum seperti dalam pesta kostum atau halloween. Cosplayer menghabiskan uang yang tidak terhitung jumlahnya, menyita waktudalam membuat, membeli kostum, mempelajari pose, dan mempelajari dialogkhas karakter yang akan mereka perankan. Pada waawancara yang telah dilakukan sebelumnya para cosplayer tidak merasa terganggu dengan kegiatan yang mereka miliki, selain harus menyiapkan segala kebutuhan cosplay secara detail, mereka harus menyelesaikan tugas tugas diluar hobinya 
seperti kuliah ataupun bekerja. Hal ini justrus menambah semangat dan motivasi mereka untuk melakukan kegiatan sehari-hari. Lotecki (dalam Pratiwi, 2014) mengatakan bahwa cosplayer merasa sukses jika bisa memainkan karakter dengan sempurna.

Morgan (dalam Soemanto, 2012) menjelaskan istilah motivasi dalam hubungan psikologi pada umumnya.Menurutnya motivasi bertalian dengan 3 hal yang sekaligus merupakan aspek-aspek dari motivasi. Ketiga hal tersebut ialah : a) Keadaan yang mendorong tingkah laku (motivating state), b) tingkah laku yang didorong oleh keadaan tersebut (motivated behavior) dan c) tujuan dari tingkah laku tersebut (goals or ends of such behavior

\section{Dukungan Sosial}

Dukungan Sosial adalah informasi atau umpan balik dari orang lain yang menunjukkan bahwa seseorang dicintai dan diperhatikan, dihargai, dan dihormati, dan dilibatkan dalam jaringan komunikasi dan kewajiban yang timbal balik (King dalam Marni dan Yuniawati 2015). Sedangkan menurut Caplin (dalam Marni dan Yuniawati, 2015) dukungan sosial adalah mengadakan atau menyediakan sesuatu untuk memenuhi orang lain, serta memberikan dorongan pengobatan semangat dan nasihat kepada orang lain dalam satu situasi dalam mengambil keputusan.

Gottlieb (dalam Smeet, 1994) menyatakan dukungan sosial terdiri dari informasi atau nasihat verbal maupun non verbal, bantuan nyata atau tindakan yang didapatkan karena kehadiran orang lain dan mempunyai manfaat emosional atau efek perilaku bagi pihak penerima.

Saroson (dalam Smeet, 1994) yang menyatakan bahwa dukungan sosial adalah adanya transaksi interpersonal yang ditunjukan dengan memberikan bantuan kepada individu lain, dimana bantuan itu umumnya diperoleh dari orang yang berarti bagi individu yang bersangkutan. Definisi lain dukungan sosial yaitu persepsi kepedulian, kepercayaan, atau bantuan yang diterima oleh seorang individu dari individu atau kelompok lain (Sarafino, dalam Savitri, 2015). House dan Kahn (dalam Apollo dan Cahyadi, 2012) dukungan social adalah tindakan yang bersifat membantu dan melibatkan emosi, pemberian informasi, bantuan instrument, dan penilaian positif pada individu dalam menghadapi permasalahannya.

House (dalam Smeet, 1994) membedakan 4 dimensi dukungan sosial, yaitu: a) Dukungan Emosional, mencakup ungkapan empati, kepedulian, dan perhatian terhadap orang yang bersangkutan, b) dukungan penghargaan, terjadi lewat ungkapan hormat (penghargaan) positif untuk orang itu, dorongan maju atau persetujuan dengan gagasan atau perasaan individu, dan perbandingan positif orang itu dengan orang lain. c) Dukungan Instrumental: mencakup bantuan langsung seperti kalau orang-orang memberi pinjaman uang kepada orang itu. d). Dukungan Informasi: mencakup memberi nasihat, petunjuk-petunjuk, saran-saran, atau umpan balik.

\section{METODOLOGI}

Metode dalam penelitian ini menggunakan metode kuantitatif. Adapun Variabel independent adalah dukungan sosial dan Variabel dependent adalah motivasi menjadi cosplayer. Populasi dalam penelitian ini adalah seluruh anggota Cosplayer Padang yang tergabung dalam COSMIC berjumlah 47 orang. Teknik pengambilan sampel dalam penelitian ini menggunakan teknik sampling jenuh yaitu teknik pengambilan dimana semua populasi dijadikan sampel penelitian (Sugiyono, 2011).

Alat ukur yang digunakan dalam penelitian ini berupa skala dukungan sosial dan skala motivasi menjadi cosplayer dengan model Likert yang telah dimodifikasi menjadi empat 
alternatif jawaban dan aitem-aitem dalam skala ini dikelompokkan dalam aitem favourable dan unfavourable. Pengujian daya deskriminasi aitem dilakukan dengan cara menghitung koefisien korelasi antara distribusi aitem dengan distribusi skor skala itu sendiri. Uji validitas dan reabilitas pada penelitian ini menggunakan Teknik Alpha Cronbach.

Sebelum dilakukan uji hipotesis terlebih dahulu dilakukan pengujian normalitas dan uji linieritas. Uji normalitas digunakan untuk mengetahui apakah populasi data berdistribusi normal atau tidak. Uji normalitas dalam penelitian ini menggunakan uji KolmogorovSmirnov. Priyatno (2008) menyatakan bahwa data yang dinyatakan berdistribusi normal jika signifikansi (p) lebih besar dari 0,05. uji linieritas bertujuan untuk mengetahui apakah dua variabel mempunyai hubungan yang linier atau tidak secara signifikan (Priyatno, 2008).Uji ini biasanya digunakan sebagai prasyarat dalam analisis korelasi.

Uji Hipotesis menggunakan teknik statistik koefisien korelasi Product Moment Pearson. Menurut Sugiyono (2011) teknik korelasi Product Moment Pearson digunakan untuk mencari dan mengetahui pola dan keeratan hubungan antara dua atau lebih variabel. Rumus yang digunakan adalah sebagai berikut :

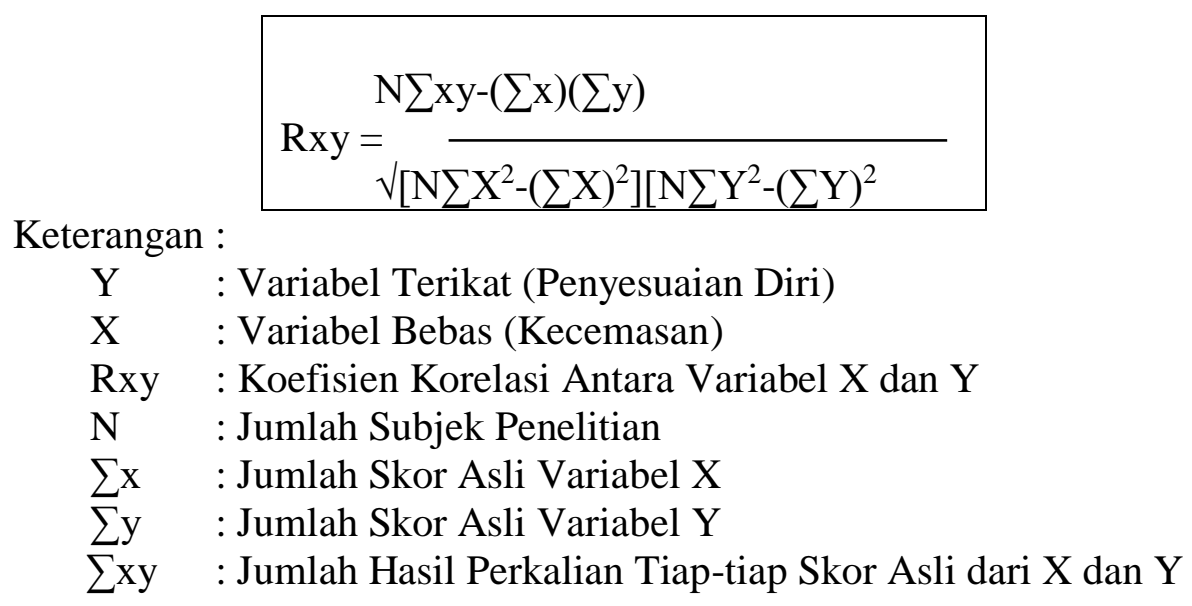

\section{HASIL}

Indeks daya beda aitem pada skala dukungan sosial bergerak dari $r_{i x}=0,337$ sampai dengan $r_{i x}=0,793$, sedangkan pada skala motivasi menjadi cosplayer bergerak dari $r_{i x}=0,330$ sampai dengan $r_{i x}=0,741$. Reliabilitas pada skala dukungan sosial $\alpha=0,890$, sedangkan pada skala motivasi menjadi cosplayer sebesar $\alpha=0,893$. Berdasarkan hasil pengolahan data untuk uji normalitas diperoleh hasil sebagai berikut :

Tabel 1. Uji Normalitas

\begin{tabular}{|l|c|c|c|c|}
\hline \multicolumn{1}{|c|}{ Variabel } & N & KSZ & p & Sebaran \\
\hline Dukungan Sosial & 47 & 1,103 & 0,176 & Normal \\
\hline $\begin{array}{l}\text { Motivasi menjadi } \\
\text { cosplayer }\end{array}$ & 47 & 0,871 & 0,474 & Normal \\
\hline
\end{tabular}

Berdasarkan tabel 1 di atas, maka diperoleh nilai signifikansi pada skala dukungan sosial sebesar $\rho=0,176$ dengan $\mathrm{KSZ}=1,103$. Hasil tersebut menunjukkan bahwa nilai $\rho>0,05$ artinya sebaran terdistribusi secara normal, sedangkan untuk skala motivasi menjadi cosplayer diperoleh nilai signifikansi sebesar $\rho=0,474$ dengan $\mathrm{KSZ}=0,871$. Hasil tersebut menunjukkan bahwa nilai $\rho>0,05$ artinya sebaran terdistribusi secara normal. Dari hasil uji linieritas, 
diperoleh nilai signifikansi sebesar $\mathrm{p}=0,043(\mathrm{p}<0,05)$, artinya varians pada dukungan sosial terhadap motivasi menjadi cosplayer tergolong linier

Hasil uji hipotesis menunjukkan besarnya koefisien kolerasi sebesar 0,296 dengan taraf signifikan $p=0,043$ artinya terdapat hubungan yang signifikan antara dukungan sosial dengan motivasi menjadi cosplayer di Padang, dengan besarnya sumbangan efektif dukungan sosial terhadap motivasi menjadi cosplayer di Padang sebesar 9\% dan 91\% lagi dipengaruhi faktor lain. Jadi koefisien korelasi hubungan antara variabel dukungan sosial dengan motivasi menjadi cosplayer tergolong rendah.

Tabel deskriptif statisitik dari variabel dukungan sosial dengan motivasi menjadi cosplayer berdasarkan mean empirik sebagai berikut :

Tabel 2. Descriptive Statistic Skala dukungan sosial dengan motivasi menjadi cosplayer

\begin{tabular}{|l|c|c|c|c|c|}
\hline \multicolumn{1}{|c|}{ Variabel } & N & Mean & Std.Deviation & Minimum & Maximum \\
\hline Dukungan sosial & 47 & 70,17 & 8,141 & 48 & 84 \\
\hline $\begin{array}{l}\text { Motivasi menjadi } \\
\text { cosplayer }\end{array}$ & 47 & 61,91 & 7,529 & 46 & 76 \\
\hline
\end{tabular}

Berdasarkan tabel 2 descriptive statistic tersebut, maka dapat dilakukan pengelompokan yang mengacu pada kriteria pengkategorisasian dengan tujuan menempatkan individu kedalam kelompok-kelompok terpisah secara berjenjang menurut suatu kontinum berdasarkan atribut yang diukur (Azwar, 2014) sebagai berikut :

Tabel 3. Norma Kategorisasi

\begin{tabular}{|c|c|}
\hline Norma & Kategorisasi \\
\hline$X<(\mu-1,0 \sigma)$ & Rendah \\
\hline$(\mu-1,0 \sigma) \leq X<(\mu+1,0 \sigma)$ & Sedang \\
\hline$(\mu+1,0 \sigma) \leq X$ & Tinggi \\
\hline
\end{tabular}

Keterangan :

$\begin{array}{ll}\mathrm{X} & \text { : raw score } \\ \mu & : \text { Mean atau rata-rata } \\ \sigma & : \text { Standar Deviasi }\end{array}$

Berdasarkan norma diatas, maka diperoleh kategorisasi subjek penelitian pada variabel dukungan sosial dengan motivasi menjadi cosplayer sebagai berikut :

Tabel 4. Kategori dukungan sosial dengan motivasi menjadi cosplayer

\begin{tabular}{|c|c|c|c|c|}
\hline Variabel & Skor & Jumlah & $\begin{array}{c}\text { Persentase } \\
(\mathbf{\%})\end{array}$ & Kategori \\
\hline \multirow{2}{*}{$\begin{array}{c}\text { Dukungan } \\
\text { sosial }\end{array}$} & $48-61$ & 6 & $13 \%$ & Rendah \\
\cline { 2 - 5 } & $62-77$ & 33 & $70 \%$ & Sedang \\
\hline \multirow{2}{*}{$\begin{array}{c}\text { Motivasi } \\
\text { menjadi } \\
\text { Cosplayer }\end{array}$} & $78-81$ & 8 & $17 \%$ & Tinggi \\
\cline { 2 - 5 } & $54-53$ & 7 & $15 \%$ & Rendah \\
\hline
\end{tabular}


Berdasarkan tabel 4 di atas, maka dapat diperoleh gambaran bahwa sebesar $13 \%$ Cosplayer dikategorikan memiliki dukungan sosial yang rendah, sebesar $70 \%$ Cosplayer dikategorikan memiliki dukungan sosial yang sedang dan 17\% Cosplayer memiliki dukungan sosial yang tinggi, sedangkan untuk variabel motivasimenjadi cosplayer diperoleh gambaran bahwa sebesar 15\% Cosplayer memiliki motivasi yang rendah, sebesar 68\% Cosplayer memiliki motivasi yang sedang dan $17 \%$ Cosplayer memiliki motivasi yang tinggi.

Adapun sumbangan efektif ( $R$ square) dari variabel dukungan sosial terhadap motivasi menjadi cosplayer dapat ditentukan dengan menggunakan rumus koefisien determinan sebagai berikut:

$$
\begin{aligned}
& \mathrm{KP}=\mathrm{r}^{2} \times 100 \% \\
& =(0,296)^{2} \times 100 \% \\
& =0,0876 \times 100 \% \\
& =9 \% \\
& \text { Keterangan: } \\
& \mathrm{KP}=\text { Nilai Koefisien Determinan } \\
& \mathrm{r} \quad=\text { Nilai Koefisien Korelasi }
\end{aligned}
$$

\section{DISKUSI}

Penelitian ini bertujuan untuk melihat hubungan antara dukungan sosial dengan motivasi menjadi cosplayer pada cosplayer di Padang. Berdasarkan hasil uji korelasi Product Momen Pearson diperoleh hasil bahwa terdapat hubungan antara dukungan sosial dengan motivasi menjadi cosplayer dengan nilai koefisien korelasi (r) sebesar $r=0,296$ dengan taraf signifikansi $\mathrm{p}=0.043$. Hal tersebut artinya bahwa semakin tinggi dukungan sosial maka semakin tinggi pula motivasi menjadi cosplayer, dan sebaliknya semakin rendah dukungan sosial maka semakin rendah pula motivasi menjadi cosplayer pada para cosplayer tersebut. Hasil penelitian ini sesuai dengan hipotesis yang diajukan yaitu terdapat hubungan yang signifikan antara dukungan sosial dengan motivasi menjadi cosplayer pada para cosplayer yang ada di kota Padang. Hal ini menyatakan bahwa hipotesis diterima dengan arah hubungan yang positif.

Dilihat dari penilain deskriptif terhadap 47 orang sampel, sebesar $12 \%$ Cosplayer dikategorikan memiliki dukungan sosial yang rendah, sebesar $70 \%$ Cosplayer dikategorikan memiliki dukungan sosial yang sedang dan $17 \%$ Cosplayer memiliki dukungan sosial yang tinggi, sedangkan untuk variabel motivasi menjadi cosplayer diperoleh gambaran bahwa sebesar 14\% Cosplayer memiliki motivasi yang rendah, sebesar 68\% Cosplayer yang memiliki motivasi yang sedang, dan $17 \%$ Cosplayer memiliki motivasi yang tinggi.

Motivasi adalah dorongan yang timbul pada diri seseorang secara sadar atau tidak sadar untuk melakukan suatu tindakan dengan tujuan tertentu.Atau usaha-usaha yang dapat menyebabkan seseorang atau kelompok orang tertentu tergerak melakukan sesuatu karena ingin mencapai tujuan yang dikehendakinya atau mendapat kepuasan dengan perbuatannya. Motivasi adalah perangsang keinginan dan daya penggerak kemauan bekerja seseorang karena setiap motif memiliki tujuan tertentu untuk dicapai (Hasibuan dalam Romli, 2014).

Motivasi merupakan perubahan energi dalam diri seseorang dalam bentuk suatu aktivitas nyata berupa kegiatan fisik.Karena seseorang mempunyai tujuan tertentu dari aktivitasnya, maka seseorang mempunyai motivasi yang kuat untuk mencapainya dengan segala upaya yang dapat dia lakukan untuk mencapainya.Jadi motivasi itu dapat dirangsang oleh faktor dari luar tetapi motivasi itu adalah tumbuh di dalam diri individu (Hamalik dalam Suardana dan Simarmata, 2013).

Dukungan sosial dan motivasi dapat berhubungan adalah karena salah satu faktor yang dapat mempengahruhi motivasi dari luar adalah adanya dukungan sosial. Menurut Ceballo dan Mclyd (dalam Pratiwi, 2017) dalam lingkungan yang baik, dukungan sosial lebih 
efektif.Sumber dukungan sosial yang paling penting adalah dari pasangan, orang tua dan keluarga. Dengan pemahaman tersebut individu akan tahu kepada siapa ia akan mendapatkan dukungan sosial sehingga dengan keinginan dan situasi yang spesifik, sehingga dukungan sosial mempunyai makna berarti bagi kedua belah pihak.

Dukungan sosial merupakan salah satu penyebab yang dapat mempengaruhi motivasi seseorang. Pada penelitian ini sumbangan efektif (R square) pada dukungan sosial terhadap motivasi pada Cosplayer di kota Padang adalah sebesar 9\%, ini berarti bahwa dukungan sosial memiliki pengaruh terhadap motivasi seseorang, dan sisanya sebesar $91 \%$ dipengaruhi oleh faktor lain. Motivasi dapat dipengaruhi oleh faktor intern dan ekstern lain seperti latar belakang kehidupan sosial budaya, pembawaan individu, pengalaman masa lampau, dan juga keinginan atau harapan masa depan terhadap suatu hal.

\section{KESIMPULAN DAN SARAN}

\section{Kesimpulan}

Berdasarkan hasil pengumpulan data dan analisis data yang telah dilakukan oleh peneliti, maka dapat ditarik kesimpulan yang sekaligus merupakan jawaban dari tujuan penelitian adalah sebagai berikut :

1. Terdapat hubungan yang signifikan antara dukungan sosial dengan motivasi menjadi cosplayer dengan arah positif, artinya semakin tinggi dukungan sosial maka semakin tinggi motivasi Cosplayer tersebut. Begitupun sebaliknya, semakin rendah dukungan sosial, maka motivasi Cosplayer tersebut akan semakin rendah.

2. Sumbangan variabel dukungan sosial dengan motivasi menjadi cosplayer adalah sebesar $9 \%$.

\section{Saran}

Berdasarkan hasil penelitian yang telah dilakukan tentang hubungan antara dukungan social dengan motivasi menjadi cosplayer pada pecinta anime dipadang, maka peneliti memberikan beberapa saran yang dapat dijadikan sebagai pertimbangan yang diharapkan dapat bermanfaat, diantaranya :

1. Bagi Cosplayer

Bagi cosplayer disarankan agar lebih dapat melakukan kegiatan cosplay dengan lebih baik, dengan membuktikan eksistensi bahwa kegiatan ini juga merupakan kegiatan yang positif sehingga bisa mendapatkan dukungan yang lebih baik lagi dari berbagai pihak, sehingga dapat meningkatkan motivasi menjadi cosplayer.

2. Bagi peneliti selanjutnya

Bagi peneliti selanjutnya, disarankan hasil penelitian ini dapat dijadikan sebagai masukan, bahan informasi dan referensi dalam melakukan penelitian lebih lanjut dengan jenis bidang yang sama. Dan bagi yang berminat mengadakan penelitian dengan topik yang sama, disarankan untuk memperhatikan faktor-faktor lain dalam motivasi menjadi cosplayer yaitu faktor internal dan eksternal lainnya seperti tujuan dan harapan individu, pengalaman masa lalu, latar belakang budaya, dan kondisi lingkungan sosial. 


\section{DAFTAR PUSTAKA}

Apollo, dan Andi Cahyadi.2012. Konflik Peran Ganda Perempuan Menikah yang Bekerja Ditinjau dari Dukungan Sosial Keluarga dan Penyesuaian Diri. Jurnal: Fakultas Khatolik Widia Mandala Madiun. No. 2

Azwar, Saifuddin. 2014. Penyusunan Skala Psikologi. Yogyakarta: Pustaka Pelajar. . 2016. Metode Penelitian. Yogyakarta: Pustaka Pelajar

Kompri.2015. Motivasi Pembelajaran Perspektif Guru dan Siswa. Bandung: Remaja Rosdakarya.

Marni, Ani dan Rudy Yuniawati. 2015. Hubungan Antara Dukungan Sosial dengan Penerimaan Diri pada Lansia Di Panti Wredha Budhi Dharma Yogyakarta. Jurnal: Fakultas Psikologi Universitas Ahmad Dahlan. Vol. 3 No. 1

Pratiwi, Lidya. 2017. Hubungan Antara Dukungan Sosial dengan Kualitias Hidup Pada Wanita di Himpunan Wanita Penyandang Disabilitas (HDWI) kota Padang. Skripsi: Universita Putra Indonesia "YPTK" Padang.

Pratiwi, Riatifani Sukma. 2014.Faktor Penyebab Perilaku Cosplayer Larp (live Action Role Playing) Pada Komunitas JCEB (Japanese Club East borneo) Samarinda. Jurnal.Semarang: Universitas Mulawarman. Vol. 2 No. 2

Priyatno, Dwi. 2008. Mandiri Belajar SPSS. Yogyakarta: Mediakom.

Romli, Khomsahrial. 2014. Komunikasi Organisasi Lengkap. Jakarta: Grasindo

Savitri, Luh Surini Yulia. 2015. Pengaruh Dukungan Sosial Terhadap Pola Pengasuhan Ornag Tua Anak Berusia Middle Childhood dari Keluarga Miskin. Jurnal Depok: Universitas Indonesia. Vol 2. No. 2

Smeet, Bart. 1994. Psikologi Kesehatan. Jakarta: Grasindo

Soemanto, Wasty. 2012. Psikologi Pendidikan. Jakarta: Rineka Cipta.

Suardana, Anak Agung Putu Chintya Putri dan Nicholas Simarmata.2013. Hubungan Antara Motivasi Belajar dengan Kecemasan pada Siswa Kelas VI Sekolah Dasar di Denpasar Menjelang Ujian Nasional.Jurnal Psikologi Universitas Udayana.Vol.1 No. 1

Sugiyono. 2013. Metode Penelitian Kuantitaid Kualitatif dan R\&D. Bandung: alfabeta 